\title{
ESTRUTURA POPULACIONAL DE CAMARÕES MARINHOS EM UM ESTUÁRIO AMAZÔNICO: ACETES MARINUS (PELÁGICO) E XIPHOPENAEUS KROYERI (BENTÔNICO)
}

\author{
Lima, F.A. ${ }^{1}$; Quaresma, M.C. ${ }^{1}$; Ferreira, V. ${ }^{1}$ \& Martinelli-Lemos, J.M. ${ }^{1}$ \\ ${ }^{1}$ Universidade Federal do Pará (UFPA), Campus Belém, Grupo de Ecologia de Crustáceos da Amazônia. \\ *Autor correspondente: lima_fal@hotmail.com
}

\begin{abstract}
Na Amazônia Oriental, estuários equatoriais servem como berçários para diversos grupos de camarões. Porém estudos sobre a estrutura populacional neste ecossistema estão aquém do necessário. O objetivo deste trabalho foi descrever a estrutura populacional de espécies que habitam diferentes posições na coluna d'água: Acetes marinus (pelágico) e Xiphopenaeus kroyeri (bentônico), em estuário da Amazônia Paraense, mesmo sendo espécies consideradas marinhas. Para tal, amostras mensais nos diferentes períodos anuais, entre 2006 e 2007, foram coletadas no canal principal e no infralitoral, seguindo o gradiente estuarino de salinidade. As espécies foram mais frequentes no período menos chuvoso, em regiões próximas ao Oceano Atlântico, com predominância de imaturos $\left(\mathrm{L}_{50}\right.$ de $17 \mathrm{~mm}$ para $X$. Kroyeri e $5 \mathrm{~mm}$ para $A$. marinus). Todos os estágios de desenvolvimento gonadal foram identificados para $X$. Kroyeri, sendo que para A. marinus não foi possível devido a integridade das amostras após a identificação da espécie. Acetes marinus habita apenas o canal principal $(n=2.607)$, não havendo ocorrência da espécie em fevereiro, março e maio; já $X$. kroyeri habita tanto o canal principal ( $\mathrm{n}=$ 5.170) quanto o infralitoral ( $n=640$ ), não ocorrendo em novembro. Estes resultados evidenciam que o estuário de Marapanim é um local essencial para recrutamento de juvenis dessas espécies, sendo que ambas utilizam este ambiente para maturação gonadal, e que $X$. kroyeri, espécie considerada exclusivamente costeira, habita não somente o canal principal do estuário, como também o infralitoral.
\end{abstract}

Palavras-chave: Decapoda, ecologia, estuário do rio Marapanim, Penaeidae, Sergestidae. 